\title{
Developing the Automatic Process for Regional Gross Nitrogen Budgets (RegNiBal)
}

\author{
Fethi Şaban OZBEK ${ }^{\mathrm{a}}$, Adrian LEIP ${ }^{\mathrm{b}}$
}

\begin{abstract}
In Europe, the Gross Nitrogen Budget (GNB) is considered to be a priority agri-environmental indicator (EC, 2006) that is of relevance for both water- and air-quality policies (Ozbek and Leip, 2015). Even though Eurostat/OECD give clear guidance on how GNB are to be estimated (Eurostat, 2013), there are still difficulties and differences of how the method is implemented by national institutes leading to results which are difficult to compare (Ozbek et al., 2015). However, many data required for the regional GNBs are already available in Eurostat data bases. Here we propose the development of an algorithm, named as "the automatic process for regional GNBs (RegNiBal)", to produce regional GNBs for European Countries. Such a tool would build on available data at EUROSTAT to produce regional (NUTS2) GNB estimations, thus reducing the reporting burden of the country (for example $\mathrm{N}$ content of crop etc.) while at the same time improving comparability of GNB estimates across countries.
\end{abstract}

Keywords - agri-environmental indicators, data collection, gross nitrogen budgets, regionalization

\section{INTRODUCTION}

Environmental assessments at regional level are needed to support the goals of EU policies, amongst them the Common Agricultural and Rural Development Policies and Nitrate and Water Framework Directives. In Europe, the Gross Nitrogen Budget (GNB) is considered to be a priority agrienvironmental indicator (EC, 2006) that is of relevance for both water- and air-quality policies (Ozbek and Leip, 2015). Ozbek and Leip (2015) showed that the regional GNB estimations are important especially for the countries environmental conditions cover large ranges or where regionally differing agricultural production systems exist. In such cases, national estimates of the GNB are inadequate for identifying targeted mitigation options.

Even though Eurostat/OECD give clear guidance on how GNB are to be estimated (Eurostat, 2013), there are still difficulties and differences of how the method is implemented by national institutes leading to results which are difficult to compare (Ozbek et al., 2015). However, many data required for the regional GNBs are already available in Eurostat data bases.

Here we propose the development of an algorithm, named as "the automatic process for regional GNBs (RegNiBal)", to produce regional GNBs for European Countries. Such a tool would build on available data at EUROSTAT to produce

Fethi Şaban OZBEK ${ }^{\mathrm{a}}$, Turkish Statistical Institute,

Adrian LEIP, ${ }^{\text {b }}$ European Commission Joint Research Centre

${ }^{1}$ The opinions and contents of the article remains the responsibility of the author, not of the Turkish Statistical Institute. regional (NUTS2) GNB estimations, thus reducing the reporting burden of the country (for example $\mathrm{N}$ content of crop etc.) while at the same time improving comparability of GNB estimates across countries.

\section{MATERIAL AND METHODS}

RegNiBal is based on Eurostat GNB methodology that describes how EU countries need to quantify gross $\mathrm{N}$ budgets (Eurostat, 2013). The methodology updates the previous guidelines (OECD and Eurostat, 2007) and is based on the land budget method (see Leip et al., 2011). A summary of the $\mathrm{N}$ inputs and outputs used in Eurostat GNB methodology, and calculation methods for related indicators (Nutrient Surplus (NS) and Nutrient Use Efficiency (NUE)) are presented in Annex 1.

The method to estimate the GNB as proposed by Eurostat and the OECD was developed under the assumption of zero changes in soil $\mathrm{N}$ stock (SSC-N), due to the lack of available data. However, studies have shown that SSC-N cannot be neglected to assess $\mathrm{N}$ efficiency properly (Ozbek and Leip, 2015). So, it is proposed in RegNiBal to load SSC-N data. If the country has no country specific SSC-N data, SSC-N can be estimated by the hyperbolic regression model based on $\mathrm{N}$ input and N-output data of GNB that allows estimating SSC-N (Equation 1\&2), developed by Ozbek and Leip (2015).

$$
\begin{array}{cc}
N_{\text {out.model }}=\frac{\alpha \cdot N_{\text {in }}}{\beta+N_{\text {in }}} & \text { Equation } 1 . \\
S S C-N=N_{\text {out }, \text { model }}-N_{\text {out }} & \text { Equation } 2 .
\end{array}
$$

Where $N_{\text {out,model }}$ is the simulated total $\mathrm{N}$ output including also changes in SSC-N, $N_{\text {in }}$ is the total $\mathrm{N}$ input in the region obtained from the statistical data, and $\alpha$ and $\beta$ are model parameters, $N_{\text {out }}$ is the observed output of $\mathrm{N}$ obtained from statistical information

\section{RESULTS AND DISCUSSION}

The GNBs have not yet been estimated officially for European Countries at the regional level. In this study, it is proposed to develop an algorithm to produce official regional GNBs for European Countries. There are basically two options in the algorithm for each GNB components: (i) automatically uploaded data from Eurostat regional databases and EMEP database and/or (ii) uploaded data by the countries.

RegNiBal automatically uses the regional data in Eurostat regional databases and EMEP (Monitoring and Evaluation of 
the Long-Range Transmission of Air Pollutants in Europe) database. These data are cropped area data in areas harvested, yields, production by NUTS 2 regions database (agr_r_crops), livestock number data in animal populations (December) by NUTS 2 regions database (agr_r_animal), mineral fertilizer use (MINFER) data in use of inorganic fertilizers database (aei_fm_usefert), land use data in land use by NUTS 2 regions (agr_r_landuse), and total atmospheric deposition data in EMEP database. The data on coefficients and contents needed for GNB estimations (e.g. $\mathrm{N}$ excretion coefficients, $\mathrm{N}$ contents of crop) need to be provided by the countries, as well as other data not available in databases (the amount of crop and fodder production, MINFER, $\mathrm{N}$ from other organic fertilizer (excl. manure)). But, in any case, the classification of the data must be same with the classifications used by Eurostat

MINFER is one of the most important components in GNB. MINFER data is available at the regional level for some countries in Eurostat aei_fm_usefert database. The Common Agricultural Policy Regional Impact model (CAPRI, Britz and Witzke, 2012) is considered as an alternative source for the regional MINFER data of the countries, which cannot provide MINFER data. CAPRI can also be considered by the countries to replace other missing data needed for GNB.

After developing RegNiBal, it is proposed to ensure a web page to download the RegNiBal tool. In order to download the RegNiBal, the authorization given by administrators defined below is needed. There will be three groups using the tool defined as follows:

User: any person authorized by the administrators

- provide requested information (name, Institute, address, aim for using etc.) for authorization
- request the authorization from administrators for installing RegNiBal and the data

Developer: the representatives of EU Members (+Norway and Switzerland) and EU Candidate States

- develop the national and the regional GNBs of their own countries by loading requested data

Administrator: Authorized person(s)

- $\quad$ authorize the users and developers

\section{REFERENCES}

[1] W. Britz and H-P Witzke, "CAPRI model documentation 2012" ed W Britz and H-P Witzke (Bonn: University Bonn) Online: http://www.caprimodel.org/dokuwiki/doku.php?id=start.

[2] EC, "Development of agri-environmental indicators for monitoring the integration of environmental concerns into the common agricultural policy. Communication from the Commission to the Council and the European Parliament. COM(2006) 508 final (Brussels: Commission of the European Communities)", 2006.

[3] Eurostat, "Nutrient Budgets, EU-27, NO, CH. Methodology and Handbook." Version 1.02 (Luxemb: Eurostat and OECD), 2013 Online: http://ec.europa.eu/eurostat/documents/2393397/2518760/Nutrient_Bud gets_Han dbook_(CPSA_AE_109)_corrected3.pdf.

[4] A. Leip, W. Britz, F. Weiss, W. de Vries, "Farm, land, and soil nitrogen budgets for agriculture in Europe calculated with CAPRI". Environ. Pollut., 2011, 159, 3243-53. doi:10.1016/j.envpol.2011.01.040.

[5] OECD and Eurostat, "Gross nitrogen balances handbook". 2007. Retrieved from: http://www.oecd.org/greengrowth/sustainableagriculture/40820234.pdf (accessed 03.03.2015).

[6] F.Ş. Özbek and A. Leip, "Estimating the gross nitrogen budget under soil nitrogen stock changes: A case study for Turkey" Agric. Ecosyst. Environ., $2015, \quad 205 \quad 48-56$ doi:http://dx.doi.org/10.1016/j.agee.2015.03.008

[7] F.Ş. Özbek, A. Leip, F. Weiss, G.C. Garcia, " Regionalisation of Nitrogen Balances with the CAPRI Model (RegNiBal)", European Commission Joint Research Centre Institute for Environment and Sustainability, European Union, Luxembourg, 2015.

ANNEX 1. INPUTS AND OUTPUTS OF GROSS NITROGEN BUDGET (GNB), AND DATA AVAILABILITY, CALCULATION METHODS AND EXPLANATIONS

\begin{tabular}{|c|c|c|c|}
\hline GNB component & $\begin{array}{l}\text { The name of Eurostat } \\
\text { database }\end{array}$ & $\begin{array}{l}\text { Data availability in } \\
\text { Eurostat database } \\
\text { (for the coverage of } \\
\text { products) }\end{array}$ & Calculation methods and explanations \\
\hline $\begin{array}{l}\text { UAA at the regional level } \\
(1000 \mathrm{ha})\left(r_{U A A}\right)\end{array}$ & $\begin{array}{l}\text { Land use by NUTS } 2 \\
\text { regions (agr_r_landuse) }\end{array}$ & & \\
\hline \multicolumn{4}{|c|}{$N_{-} I N P U T S=N \_M I N F E R+N_{-} O R G F E R+N \_E X C R E T+N \_B I O F I X+N \_A T M D E P+N \_S E E D$} \\
\hline $\begin{array}{l}\mathrm{N} \text { from mineral fertilizer use } \\
\left(N_{-} M I N F E R\right)(\mathrm{Gg} / \mathrm{ha} / \mathrm{yr})\end{array}$ & & & $N_{-} M I N F E R=M I N F E R / r_{U A A}$ \\
\hline $\begin{array}{l}\mathrm{N} \text { amount of mineral } \\
\text { fertilizer use }(M I N F E R) \\
\text { (ton/yr) }\end{array}$ & $\begin{array}{l}\text { Use of inorganic } \\
\text { fertilizers (aei_fm_usefert) }\end{array}$ & $\begin{array}{l}\text { MINFER data is } \\
\text { available at the } \\
\text { regional level for some } \\
\text { countries in Eurostat } \\
\text { database } \\
\text { (aei_fm_usefert). }\end{array}$ & $\begin{array}{l}\text { In the tool, there will be } 2 \text { options (i) directly extracting the } \\
\text { data from Eurostat database (aei_fm_usefert) } \\
\text { (ii) loading the data by the developer }\end{array}$ \\
\hline
\end{tabular}




\begin{tabular}{|c|c|c|c|}
\hline $\begin{array}{l}\mathrm{N} \text { from other organic } \\
\text { fertilizer } \\
(\mathrm{Gg} / \mathrm{ha} / \mathrm{yr})\end{array}$ & & & $\begin{array}{l}\text { The developer needs to load the NUTS } 2 \text { data of (i) the } \\
\text { amount of organic fertilizer use } \mathrm{i}\left(o_{\text {orgfer }} i\right)(1000 \text { ton } / \\
y r) \text { and } \\
\text { (ii) } \mathrm{N} \text { content of organic fertilizer i }\left(n_{\text {orgfer }_{-} i}\right)(\mathrm{kg} \mathrm{N} / \\
\text { ton }) \text { into the tool } \\
N_{-} O R G F E R=\sum_{i} o_{\text {orgfer } i} * n_{\text {orgfer }} i / r_{U A A}\end{array}$ \\
\hline $\begin{array}{l}\mathrm{N} \text { from manure excretion } \\
\left(N_{-} E X C R E T\right)(\mathrm{Gg} / \mathrm{ha} / \mathrm{yr})\end{array}$ & & & $N_{-} E X C R E T=\sum_{i} n_{\text {animal_i}} * c_{\text {excret_i }} / r_{U A A}$ \\
\hline $\begin{array}{l}\text { Number of animals } \\
\left(n_{\text {animal_i }}\right)(1000 \text { heads })\end{array}$ & $\begin{array}{l}\text { Animal populations } \\
\text { (December) by NUTS } 2 \\
\text { regions (agr_r_animal) }\end{array}$ & $\begin{array}{l}\text { Poultry and other } \\
\text { livestock categories' } \\
\text { data are not available } \\
\text { in the database } \\
\text { (agr_r_animal). These } \\
\text { data will be requested } \\
\text { from developer by the } \\
\text { tool. }\end{array}$ & $\begin{array}{l}\text { In the tool, there will be } 2 \text { options (i) directly extracting the } \\
\text { data from Eurostat database (agr_r_animal) and } \\
\text { completing the missing data by the developer. } \\
\text { (ii) loading the data by the developer }\end{array}$ \\
\hline $\begin{array}{l}\text { Manure } \mathrm{N} \text { excretion } \\
\text { coefficients }\left(c_{\text {excret } i}\right) \\
(\mathrm{kg} \mathrm{N} / \mathrm{head} / \mathrm{yr})\end{array}$ & & & $\begin{array}{l}\text { The developer needs to load the table of manure } \mathrm{N} \\
\text { excretion coefficients into the tool. }\end{array}$ \\
\hline $\begin{array}{l}\mathrm{N} \text { from manure trade, } \\
\text { withdrawal, and treatment } \\
\text { (N_MAN_TRADE) } \\
(\mathrm{Gg} / \mathrm{ha} / \mathrm{yr})\end{array}$ & & & $\begin{array}{l}\text { (i) Data on manure export and import are required if } \\
\text { significant (net import or net export }>=5 \% \text { of } \\
\text { manure nutrient production). } \\
\text { (ii) Data on manure treatment and non-agricultural use are } \\
\text { optional. } \\
\text { (iii) The developer needs to load the NUTS } 2 \text { data into the } \\
\text { tool }\end{array}$ \\
\hline $\begin{array}{l}\text { Biological } \quad \mathrm{N} \quad \text { fixation } \\
\left(N_{-} B I O F I X\right)(\mathrm{Gg} / \mathrm{ha} / \mathrm{yr})\end{array}$ & & & $\begin{array}{l}N_{\text {BIOFIX }} \\
=\left(\sum_{i} s a_{\text {crops }_{i}}\left(\text { or } p_{\text {crops }}\right) * f x_{\text {crop }}+a_{\text {perm }} * f x_{\text {grass }}\right) / r_{U A A}\end{array}$ \\
\hline $\begin{array}{l}\text { The area/production } \text { of } \\
\text { leguminous crop i \& of } \\
\text { temporary grasses and } \\
\text { grazing }\left(\mathrm{sa}_{\text {crops_i }} \text { OR } \mathrm{p}_{\text {crops_i }}\right) \\
(1000 \text { ha } / 1000 \text { ton })\end{array}$ & & & The developer needs to load the data into the tool. \\
\hline $\begin{array}{l}\text { The fixation coefficient of } \\
\text { leguminous crop i \& of } \\
\text { temporary grasses and } \\
\text { grazing }\left(\mathrm{fx}_{\text {crop_i }}\right)(\mathrm{kg} \mathrm{N} / \mathrm{ha} \mathrm{OR} \\
\mathrm{kg} \mathrm{N} / \text { ton })\end{array}$ & & & The developer needs to load the coefficients into the tool. \\
\hline $\begin{array}{l}\text { The area of permanent } \\
\text { grassland }\left(\mathrm{a}_{\text {perm }}\right)(1000 \mathrm{ha})\end{array}$ & $\begin{array}{l}\text { Land use by NUTS } 2 \\
\text { regions (agr_r_landuse) }\end{array}$ & & \\
\hline $\begin{array}{l}\text { The fixation coefficient of } \\
\text { grass/legume mixtures } \\
\left(\mathrm{fx}_{\text {grass }}\right)(\mathrm{kg} \mathrm{N} / \mathrm{ha})\end{array}$ & & & The developer needs to load the coefficients into the tool. \\
\hline $\begin{array}{l}\text { Atmospheric deposition } \\
\left(N_{-} A T M D E P\right)(\mathrm{Gg} / \mathrm{ha} / \mathrm{yr})\end{array}$ & & & $N_{-} A T M D E P=r_{\text {atmdep }}$ \\
\hline $\begin{array}{l}\text { Total atmospheric deposition } \\
(\mathrm{Gg} / \mathrm{yr})\left(T_{\text {atmdep }}\right)\end{array}$ & EMEP database & & \\
\hline $\begin{array}{l}\text { Total area at national level } \\
(1000 \mathrm{ha})\left(a_{\text {atmdep }}\right)\end{array}$ & $\begin{array}{l}\text { Land use by NUTS } 2 \\
\text { regions (agr_r_landuse) }\end{array}$ & & \\
\hline $\begin{array}{lr}\text { Regional } & \text { atmospheric } \\
\text { deposition } & \text { rate } \quad(\mathrm{Gg} / \mathrm{ha} / \mathrm{yr}) \\
\left(r_{\text {atmdep }}\right) & \end{array}$ & & & $\begin{array}{l}\text { In the tool, there will be } 2 \text { options (i) Tool estimate } \\
r_{\text {atmdep }} \\
r_{\text {atmdep }}=\left(\frac{T_{\text {atmdep }}}{1000 * a_{\text {atmdep }}}\right) \\
\text { (ii) the developer loads } r_{\text {atmdep }} \text { into the tool for each } \\
\text { NUTS2 region. }\end{array}$ \\
\hline
\end{tabular}




\begin{tabular}{|c|c|c|}
\hline $\begin{array}{l}\mathrm{N} \text { from seed and planting } \\
\text { materials }\left(N_{-} S E E D\right) \\
(\mathrm{Gg} / \mathrm{ha} / \mathrm{yr})\end{array}$ & & $\begin{array}{l}\text { In the tool, there will be } 2 \text { options (i) Tool estimates } \\
N_{-} S E E D \text { by using Eurostat default nutrient seed input } \\
\text { rates and the cropped areas of wheat, other cereals, and } \\
\text { potatoes } \\
N_{-} S E E D=\sum_{i}^{n}\left(\text { sa }_{\text {crop_i }} * i_{\text {seed_i }}\right) / r_{U A A} \\
\text { (ii) OR the developer loads country specific coefficients } \\
N_{-} S E E D \\
=\sum_{i}^{n}\left(\text { sa }_{\text {crop }_{i}} * r_{\text {sowing }_{i}} * N_{\text {seed }_{i}}\right) /\left(1000 * r_{U A A}\right)\end{array}$ \\
\hline $\begin{array}{l}\text { Cropped areas of crop i at } \\
\text { regional level (ha) } \\
\left(s a_{\text {crop } \_i}\right)\end{array}$ & $\begin{array}{l}\text { Areas harvested, yields, } \\
\text { production by NUTS } 2 \\
\text { regions (agr_r_crops) }\end{array}$ & \\
\hline $\begin{array}{l}\text { Sowing rates of crop i }(\mathrm{kg} \\
\text { seed per ha) }\left(r_{\text {sowing }_{-} i}\right)\end{array}$ & & The developer needs to load the rates into the tool. \\
\hline $\begin{array}{l}\mathrm{N} \text { content of seed of crop } \mathrm{i} \\
(\mathrm{kg} \mathrm{N} \text { per tonne biomass }) \\
\left(N_{\text {seed_i }} i\right)\end{array}$ & & The developer needs to load the coefficients into the tool. \\
\hline $\begin{array}{l}\mathrm{N} \text { seed input rate of wheat, } \\
\text { other cereals, and potateos } \\
\left(\mathrm{kg} \mathrm{N} \text { per ha) }\left(i_{\text {seed_i }}\right)\right.\end{array}$ & & Tool uses Eurostat default nutrient seed input rates. \\
\hline
\end{tabular}

\section{OUTPUTS}

\section{$N \_O U T P U T S=N \_C R O P S+N \_F O D D E R S+N \_R E M O V E D \& B U R N T+S S C-N$}

\begin{tabular}{|c|c|c|}
\hline $\begin{array}{l}\mathrm{N} \text { removed with crops }\left(N_{-} C R O P S\right) \\
(\mathrm{Gg} / \mathrm{ha} / \mathrm{yr})\end{array}$ & & $N_{-} C R O P S=\sum_{i}\left(p_{\text {fodder } i_{-} i} * c_{\text {fodder }_{-}}\right) / r_{U A A}$ \\
\hline $\begin{array}{l}\text { The amount of crop production of crop i } \\
(1000 \text { ton/yr })\left(p_{\text {crop }_{-} i}\right)\end{array}$ & $\begin{array}{l}\text { Areas harvested, } \\
\text { yields, production } \\
\text { by NUTS } 2 \text { regions } \\
\text { (agr_r_crops) }\end{array}$ & $\begin{array}{l}\text { The developer needs to load the regional crop production } \\
\text { data into the tool. } \\
\text { If the full coverage of crops types is available in Eurostat } \\
\text { database (agr_r_crops) then the tool can directly extract crop } \\
\text { production data from the database. }\end{array}$ \\
\hline $\mathrm{N}$ content of crop i (kg N/ton) $\left(c_{\text {crop }_{-}} i\right)$ & & $\begin{array}{l}\text { The developer needs to load the regional } \mathrm{N} \text { content data into } \\
\text { the tool. }\end{array}$ \\
\hline $\begin{array}{l}\mathrm{N} \text { removed with fodders } \\
\left(N_{-} F O D D D E R S\right)(\mathrm{Gg} / \mathrm{ha} / \mathrm{yr})\end{array}$ & & $N_{-}$FODDERS $=\sum_{i}\left(p_{\text {fodder }_{-} i} * c_{\text {fodder }_{-} i}\right) / r_{\text {UAA }}$ \\
\hline $\begin{array}{l}\text { The amount of crop production of } \\
\text { fodder i }\left(p_{\text {fodder } \_} i\right)\end{array}$ & & $\begin{array}{l}\text { The developer needs to load the regional fodder production } \\
\text { data into the tool. }\end{array}$ \\
\hline $\mathrm{N}$ content of fodder $\mathrm{i}\left(c_{\text {fodder }_{-} i}\right)$ & & $\begin{array}{l}\text { The developer needs to load the regional } \mathrm{N} \text { content data into } \\
\text { the tool. }\end{array}$ \\
\hline $\begin{array}{l}\mathrm{N} \text { removal with crop residues } \\
\text { removed/burnt } \\
\left(N_{-} R E M O V E D \& B U R N T\right)(\mathrm{Gg} / \mathrm{ha} / \mathrm{yr})\end{array}$ & & $\begin{array}{l}\text { N_REMOVED\&BURNT } \\
=N_{-} R E M O V E D+N_{-} B U R N T \\
\text { According to the practical implementation of the } \\
\text { Eurostat/OECD Guideline, countries may report the total } N \\
\text { removal with crop residues harvested from the field } \\
\text { (Nres_harvest) as an approximation of the net } \\
N_{-} \text {REMOVED. The Nres_harvest can be estimated with } \\
\text { IPCC 2006 Tier } 1 \text { (see Equation } 79 \text { in Eurostat/OECD } \\
\text { guideline). }\end{array}$ \\
\hline
\end{tabular}


Int'I Journal of Advances in Chemical Engg., \& Biological Sciences (IJACEBS) Vol. 4, Issue 1 (2017) ISSN 2349-1507 EISSN 2349-1515

\begin{tabular}{|c|c|c|}
\hline Stock changes of $\mathrm{N}$ in soil $\left(N_{\Delta \text { soil }}\right)$ & & $\begin{array}{l}\text { SSC-N }=\mathrm{N}_{\text {out }, \text { model }}-\mathrm{N}_{\text {out }} \\
\left.\mathrm{N}_{\text {out.model }}=\frac{\alpha \cdot \mathrm{N}_{\text {in }}}{\beta+\mathrm{N}_{\text {in }}} \quad \text { (see Section } 2\right)\end{array}$ \\
\hline INDICATORS & $\begin{array}{l}\text { N Surplus (NS) }(\mathrm{Gg} / \mathrm{ha} / \mathrm{yr}) \\
\mathbf{N} \text { use efficiency (NUE) }(\%)\end{array}$ & $\begin{array}{l}=N \_I N P U T S-N \_O U T P U T S \\
E=\left(N \_O U T P U T S / N \_I N P U T S\right) * 100\end{array}$ \\
\hline
\end{tabular}

Note (1): Main GNB components to be produced/disseminated by RegNiBal tool are shown in grey rows. 